\title{
Partisipasi Pemuda Memberhasilkan Organisasi Karang Taruna di Kabupaten Tapanuli Utara
}

\author{
Desy Yanty Silaban ${ }^{1}$, Elizon Nainggolan ${ }^{2} *$ \\ ${ }^{1,2)}$ Fakultas Ilmu Pendidikan, Universitas Negeri Medan \\ *elizonnainggo06@gmail.com
}

\begin{abstract}
Abstrak
Rendahnya kesadaran berorganisasi, minimnya kontribusi dan kurangnya rasa percaya diri berdampak pada ketidakmampuan mengembangkan bakat yang dimiliki. Penelitian ini bertujuan mengetahui tingkat partisipasi pemuda dalam memberhasilkan organisasi. Metode yang digunakan adalah deskriptif kuantitatif. Seluruh angota organisasi Karang Taruna di Kecamatan Pagaran Kabupaten Tapanuli Utara terlibat sebagai subjek penelitian, yaitu sebanyak 63 orang. Pengumpulan data penelitian dilakukan dengan menggunakan angket. Teknik analisis data yang digunakan adalah mean, median, modus, dan standar deviasi. Hasil penelitian menunjukkan bahwa partisipasi pemuda dalam memberhasilkan organisasi Karang Taruna di Kecamatan Pagaran Kabupaten Tapanuli Utara adalah baik dalam perencanaan program organisasi, pelaksanaan program, pemanfaatan hasil dan pengevaluasian program. Penelitian lebih lanjut perlu dilakukan untuk dapat meningkat keterlibatan pemuda dan steakholder.
\end{abstract}

Kata Kunci: Pemuda, Organisasi, Kabupaten Tapanuli Utara

\begin{abstract}
The low awareness of organization, lack of contribution, and lack of confidence has an impact on the inability to develop their talents. This study aims to determine the level of youth participation in the organization. The method used is descriptive quantitative. All members of Karang Taruna organization in Pagaran Sub-district, North Tapanuli Regency are involved as research subjects, which are 63 people. The data were collected using questionnaires. Data analysis techniques used are mean, median, mode, and standard deviation. The results showed that youth participation in producing the organization of Karang Taruna in Kecamatan Pagaran Kabupaten Tapanuli Utara was good in planning of organization program, program implementation, utilization of result and program evaluation. Further research needs to be done to increase the involvement of youth and steakholder.
\end{abstract}

Keywords: Youth, Organization, Kabupaten Tapanuli Utara

\section{PENDAHULUAN}

Organisasi Karang Taruna seharusnya mendapatkan perhatian lebih dari masyarakat, pemerintah serta pihak-pihak yang terkait. Dikarenakan akhir-akhir ini banyak pemuda-pemudi yang kurang mendapatkan perhatian serta sulitnya untuk mengekspresikan diri, sehingga kita dapat melihat apa yang pemuda lakukan saat ini 
adalah hal-hal yang tidak diharapkan oleh semua pihak. Dalam organisasi Karang Taruna di Kecamatan Pagaran Kab.Tapanuli Utara masih ada pemuda-pemudi yang belum memiliki kesadaran akan pentingnya organisasi sehingga anggota bersifat kurang aktif dan belum dapat menggunakan waktu untuk menyalurkan bakatnya dalam organisasi karang taruna. Anggota organisasi Karang Taruna di Kecamatan Pagaran mayoritas sudah bekerja dan berstatus mahasiswa.Anggota organisasi karang taruna yang masih berstatus mahasiswa menganggap bahwa status keanggotaan mereka hanya mengikuti setiap kegiatan yang diadakan oleh karang taruna saja, dan tidak menyalurkan aspirasi yang dimiliki untuk mengajukan pendapat mereka.

Hal ini terbukti dengan kurang kontribusi mereka dalam upaya peningkatan program kinerja organisasi karang taruna.Kurangnya inisiatif anggota organisasi karang taruna Kecamatan Pagaran mengakibatkan program organisasi karang taruna kurang berjalan dengan semestinya.Selain itu, Sumber Daya Manusia (SDM) yang professional masih sangat terbatas karena hanya pengurus saja yang memiliki SDM cukup memadai. Hal ini didukung dari ilmu maupun pengalaman yang mereka dapatkan di jenjang pendidikan yang lebih dari anggota lain. Kurangnya rasa kepercayaan diri juga menjadi penyebab anggota karang taruna tidak dapat mengembangkan bakat, keterampilan yang dimiliki.Dari permasalahan tersebut menyebabkan organisasi karang taruna di Kabupaten Pagaran kurang berjalan dengan baik sebagaimana mestinya.

Dalam penelitian terdahulu yang dilakukan oleh Nurul Sawitri yang berjudul "Partisipasi Pemuda dalam Program Karang Taruna Desa Kupang Kecamatan Ambarawa" pada tahun 2014 menyatakan bahwa ada tiga buah unsur penting dalam partisipasi yaitu: (1) Partisipasi merupakan suatu keterlibatan mental dan perasaan lebih dari semata-mata atau hanya keterlibatan secara jasmaniah. (2) Ketersediaan memberi sesuatu sumbangan kepada usaha mencapai tujuankelompok, ini berarti terdapat rasa senang, kesukarelaan untuk membantu kelompok. (3) Dalam partisipasi harus ada tanggung jawab, unsur tanggung jawab ini merupakan segi yang menonjol dari rasa menjadi anggota. Dari uraian jelaslah bahwa partisipasi menyangkut keterlibatan diri/ego dan tidak semata-mata keterlibatan fisik dalam pekerjaan atau tugas saja, dan ketiga unsur partisipasi tersebut di dalam realitanya tidak akan terpisahkan satu sama lain, tetapi akan saling menunjang.

Sementara dari hasil penelitian yang dilakukan pada anggota organisasi Karang Taruna di Kec.Pagaran Kab. Tapanuli Utara memiliki: (1) Rasa kurang percaya diri dari anggota organisasi untuk menampilkan bakat yang dimiliki. (2) Adanya sifat tidak 
peduli kepada organisasi dikarenakan adanya kesibukan pribadi dari tiap anggota. (3) Kurangnya Sumber Daya Manusia yang professional yang dimiliki oleh organisasi untuk memajukan program Karang Taruna di Kecamatan Pagaran Kab. Tapanuli Utara. Dari hasil uraian perlu dilakukan penelitian dengan judul "Partisipasi Pemuda dalam Memberhasilkan Organisasi Karang Taruna di Kecamatan Pagaran Kabupaten. Tapanuli Utara"

Berdasarkan uraian yang telah diutarakan dalam latar belakang masalah, dapat diidentifikasikan berbagai hal dan/faktor yang berkaitan dengan kurang berfungsinya organisasi Karang Taruna :

1. Masih rendahnya kesadaran yang dimiliki oleh anggota karang taruna dalam berorganisasi.

2. Kurangnya partisipasianggota karang taruna dalam menjalankan program organisasi.

3. Kurangnya inisiatif anggota karang taruna untuk memberhasilkan organisasi karang taruna.

4. Terbatasnya kemampuan Sumber Daya Manusia untuk mengembangkan organisasi karang taruna.

5. Kurangnya rasa percaya diri yang dimiliki anggota untuk menyalurkan bakat menghambat berlangsungnya program karang taruna.

Berdasarkan batasan masalah di atas adalah bagaimana tingkat partisipasi pemuda dalam memberhasilkan organisasi Karang Taruna di Kecamatan Pagaran Kabupaten Tapanuli Utara? Dengan demikian, penelitian ini bertujuan mengetahui tingkat partisipasi pemuda dalam memberhasilkan Karang Taruna di Kecamatan Pagaran KabupatenTapanuli Utara.

Penelitian ini bermanfaat baik secara teoritis dan praktis. Secara teoritis adalah (1) sebagai bahan masukan terhadap instansi yang terkait secara khusus Perangkat Desa dan Pihak Pemerintah guna penyempurnaan pengembangan generasi muda di masa mendatang; (2) Menambah ilmu pengetahuan bagi mahasiswa, khususnya mahasiswa bidang pendidikan tentang partisipasi pemuda dalam memberhasilkan organisasi Karang Taruna.

Secara praktis adalah (1) sebagai upaya awal untuk mengetahui pentingnya organisasi karang taruna dalam pengembangan generasi muda. (2) sebagai masukan bagi anggota Karang Taruna Kecamatan Pagaran dalam memberhasilkan organisasi. 


\section{KAJIAN TEORI}

Jhon (Suryosubroto, 2012) mengemukakan bahwa "Partisipasi adalah keterlibatan di dalam proses pembuatan keputusan, pelaksanaan program, pengambilan manfaat, dan pengevaluasian hasil”. Sedangkan Keith Davis (Suryosubroto, 2012) mengatakan bahwa "Partisipasi adalah keterlibatan mental dan pikiran individu di dalam suatu kelompok yang mendorongnya untuk mengembangkan kemampuan sesuai dengan tujuan kelompok tersebut".

Verhangen (Mardikanto, 2015) menyatakan bahwa "Partisipasi adalah suatu bentuk khusus dari interaksi dan komunikasi yang berkaitan dengan pembagian kewenangan, tanggung jawab, dan manfaat". Faktor-faktor yang mempengaruhi terhadap tumbuh dan berkembangnya partisipasi dapat dilihat dengan beragam pendekatan disiplin keilmuan.Menurut konsep proses pendidikan, partisipasi merupakan bentuk tanggapan atau respon atas rangsangan-rangsangan yang diberikan; yang dalam hal ini, tanggapan merupakan fungsi dari manfaat (rewards) yang dapat diharapkan.

Dari definisi para ahli yang telah diuraikan dapat disimpulkan bahwa partisipasi adalah keikutsertaan, bentuk kerja sama, peran serta atau keterlibatan individu dalam kelompok sosial yang berkaitan dengan tujuan pengembangan masyarakat. Berdasarkan uraian tersebut dapat disimpulkan bahwa adanya partisipasi bukanlah merupakan suatu paksaan melainkan harus dengan rasa sadar dan rela dengan penuh tanggung jawab. Menurut Pariata Westra (Suryosubroto, 2012), agar partisipasi dapat tercapai dengan baik, pemuda harus memperhatikan beberapa prasyarat partisipasi antara lain: (a) Tersedianya waktu yang cukup untuk mengadakan partisipasi karena partisipasi sulit dilaksanakan dalam keadaan serba darurat; (b) Pembiayaan partisipasi hendaknya tidak melebihi hasil-hasil yang akan diperoleh serta memperhatikan segi-segi penghematan; (c) pelaksana partisipasi harus memandang pentingnya keberadaan kelompok kerja yang akan dipartisipasikan; (d) peserta partisipasi harus mempunyai kemampuan khusus sehingga efektif untuk dipartisipasikan; (e) Pelaku partisipasi harus dapat berhubungan secara timbal balik sehingga dapat saling bertukar ide dengan pengertian dan bahasa yang sama; (f) Tidak ada pihak-pihak yang merasa bahwa posisinya terancam akibat adanya partisipasi; dan (g) Partisipasi akan lebih efektif jika didasarkan asas kebebasan bekerja.

Dari penjelasan mengenai prasyarat partisipasi di atas, dapat disimpulkan bahwa syarat tercapainya partisipasi adalah :(a) Tersedianya waktu untuk berpartisipasi; (b) Orang yang berpartisipasi harus mempunyai kemampuan untuk berpartisipasi; (c) 
Adanya komunikasi dalam berpartisipasi; (d) Tersedianya biaya yang cukup; (e) Tidak merugikan pihak lain; (f) Keterikatan anggota dengan tujuan yang dicapai.

\section{Program Karang Taruna Kecamatan Pagaran}

Adapun jenis-jenis kegiatan untuk mencapai tujuan, fungsi dan tugas Karang Taruna di Kecamatan Pagaran adalah sebagai berikut: (1) Kegiatan Sosial. Kegiatan sosial yang dilakukan oleh Karang Taruna mencakup antara lain: (a) mengunjungi serta membantu masyarakat yang terkena musibah; (b) membantu dalam acara atau pesta adat kapan saja diperlukan; (2) Kegiatan Kesenian. Kegiatan kesenian berhubungan dengan pelestarian kebudayaan yang dilakukan oleh Karang Taruna di Desa Sipultak antara lain: (a) Mengembangkan bakat dalam bidang kesenian batak toba, (b) Melestarikan pakaian adat batak toba. (3) Kegiatan Olahraga; (a) Olahraga Volly yang bertujuan untuk mempererat hubungan muda-mudi dengan masyarakat, (b) Mengadakan pertandingan Volly antara anggota karang taruna dengan masyarakat sekitar Desa Sipultak; (4) Kegiatan Gotong Royong; (a) Membersihkan lingkungan di Desa Sipultak, (b) Menjaga dan mengawasi kebersihan lingkungan, (c) Ikut serta mengambil bagian dalam pelaksanaan go green seperti penanaman seribu pohon.

Ada beberapa faktor yang dapat mempengaruhi partisipasi masyarakat dalam suatu program, sifat faktor-faktor tersebut dapat mendukung suatu keberhasilan program namun ada juga yang sifatnya dapat menghambat keberhasilan program. Faktor-faktor yang mempengaruhi kecenderungan seseorang dalam berpartisipasi yaitu :

1. Usia

Faktor usia merupakan faktor yang mempengaruhi sikap seseorang terhadap kegiatan-kegiatan kemasyarakatan yang ada. Mereka dari kelompok usia menengah ke atas dengan keterikatan moral kepada nilai dan norma masyarakat yang lebih mantap, cenderung lebih banyak yang berpartisipasi dari pada mereka yang dari kelompok usia lainnya.

2. Jenis kelamin

Nilai yang cukup lama dominan dalam kultur berbagai bangsa mengatakan bahwa pada dasarnya tempat perempuan adalah "dapur" yang berarti bahwa dalam banyak masyarakat peranan perempuan yang terutama adalah mengurus rumah tangga.

3. Pendidikan 
Dikatakan sebagai salah satu syarat mutlak untuk berpartisipasi. Pendidikan dianggap dapat mempengaruhi sikap hidup seseorang terhadap lingkungannya, suatu sikap yang diperlukan bagi peningkatan kesejahteraan seluruh masyarakat.

4. Pekerjaan dan Penghasilan

Hal ini tidak dapat dipisahkan satu sama lain karena pekerjaan seseorang akan menentukan berapa penghasilan yang akan diperolehnya. Pekerjaan dan penghasilan yang baik dan mencukupi kebutuhan sehari-hari dapat mendorong seseorang untuk berpartisipasi dalam kegiatan masyarakat.

\section{METODE PENELITIAN}

Penelitian ini adalah penelitian deskriptif kuantitatif yaitu bertujuan untuk menggambarkan dan mengungkapkan suatu masalah keadaan peristiwa yang timbul dimasyarakat berdasarkan apa yang sedang terjadi. Dalam penelitian ini, penulis ingin mengetahui bagaimana Partisipasi Pemuda dalam Memberhasilkan Organisasi Karang Taruna di Kecamatan Pagaran Kabupaten Tapanuli Utara.

Populasi merupakan objek atau subjek yang berada pada suatu wilayah dan memenuhi syarat-syarat tertentu berkaitan dengan masalah penelitian Morissan (2012:109). Berdasarkan pendapat ini, maka yang menjadi populasi dalam penelitian ini adalah anggota Karang Taruna Kecamatan Pagaran yang berjumlah 63 orang.

Dalam mengambil sampel dilakukan dengan sampling total dan menentukan besarnya sampel, maka penulis mengutip pendapat Arikunto (2006:123) mengatakan bahwa: "Apabila subjek kurang dari 100 orang, lebih baik diambil semuanya dan apabila jumlahnya lebih banyak maka diambil sekitar 10-15\% atau 20-25\% atau lebih". Berdasarkan pendapat tersebut, jumlah populasi sebanyak 63 orang. Jadi sampel penelitiannya sebanyak 63 orang.

Angket (kuesioner) adalah teknik pengumpulan data yang dilakukan dengan cara memberi seperangkat pertanyaan atau pertanyaan tertulis kepada respon dan untuk dijawabnya (Sugiyono, 2014). Angket digunakan untuk mengetahui data mengenai partisipasi pemuda dalam memberhasilkan organisasi karang taruna di Kecamatan Pagaran Kabupaten Tapanuli Utara. Di dalam angket berisikan pertanyaan berbentuk pilihan berganda. Jenis angket yang digunakan dalam penelitian ini adalah tertutup menggunakan skala likert, dimana jawaban dari pertanyaan tersebut telah disediakan sehingga responden tinggal memilih jawabannya. Jawaban setiap item instrument 
menggunakan skala likert mempunyai gradasi dari sangat positif sampai negative yaitu dengan pilihan jawaban berjumlah empat ( $a, b, c$ dan $d$ ) dengan skor:

a. Pilihan jawaban a skor 4 menyatakan selalu

b. Pilihan jawaban b skor 3 menyatakan sering

c. Pilihan jawaban c skor 2 menyatakan kadang-kadang

d. Pilihan jawaban d skor 1 menyatakan tidak pernah

Tabel 1. Kisi-kisi Angket Partisipasi Pemuda dalam Memberhasilkan Organisasi Karang Taruna

\begin{tabular}{|c|c|c|}
\hline Variabel & Sub-variabel & Indikator \\
\hline \multirow[t]{4}{*}{$\begin{array}{l}\text { Partisipasi Pemuda } \\
\text { dalam Memberhasilkan } \\
\text { Organisasi Karang } \\
\text { Taruna }\end{array}$} & $\begin{array}{l}\text { 1. Partisipasi } \\
\text { Perencanaan }\end{array}$ & $\begin{array}{l}\text { 1.1. Rekrutmen anggota perencanaan } \\
\text { program kegiatan } \\
\text { 1.2. Perencanaan program Karang } \\
\text { Taruna } \\
\text { 1.3 Perencanaan anggaran program }\end{array}$ \\
\hline & $\begin{array}{l}\text { 2. Partisipasi } \\
\text { Pelaksanaan }\end{array}$ & $\begin{array}{l}\text { 2.1 Pelaku pelaksanaan program } \\
\text { 2.2 Sarana dan prasarana pendukung } \\
\text { program }\end{array}$ \\
\hline & $\begin{array}{l}\text { 3. Partisipasi } \\
\text { Pemanfaatan } \\
\text { Hasil }\end{array}$ & $\begin{array}{l}\text { 3.1. Pemanfaatan program } \\
\text { 3.2. Pengembangan Program }\end{array}$ \\
\hline & $\begin{array}{l}\text { 4. Partisipasi } \\
\text { Pengevaluasian } \\
\text { program }\end{array}$ & $\begin{array}{l}\text { 4.1. Menilai keberlangsungan } \\
\text { program } \\
\text { 4.2. Memberi kritik dan saran } \\
\text { terhadap program }\end{array}$ \\
\hline
\end{tabular}

Tabel 2. Mean, median, modus, standar deviasi Pengetahuan kecenderungan partisipasi

\begin{tabular}{cccc}
\hline Kelompok & F.Absolut & F.Relatif $(\%)$ & Kategori \\
\hline (Mi+1,5Sdi) - ke atas & N1 & N1/N x 100\% & Sangat Baik \\
Mi $-(\mathrm{Mi}+1,5 \mathrm{Sdi})$ & $\mathrm{N} 2$ & $\mathrm{~N} 2 / \mathrm{N} \times 100 \%$ & Baik \\
$(\mathrm{Mi}+1,5 \mathrm{Sdi})-\mathrm{Mi}$ & $\mathrm{N} 3$ & $\mathrm{~N} 3 / \mathrm{N} \times 100 \%$ & Cukup Baik \\
$(\mathrm{Mi}+1,5 \mathrm{Sdi})-$ ke bawah & $\mathrm{N} 4$ & $\mathrm{~N} 4 / \mathrm{N} \times 100 \%$ & Kurang Baik \\
\hline
\end{tabular}

Untuk mencari harga rata-rata ideal (Mi) dan standar deviasi ideal (Sdi) digunakan rumus:

$$
\begin{gathered}
M i=\frac{\text { skor tertinggi }+ \text { skor terendah }}{2} \\
S d i=\frac{\text { skor tertinggi }- \text { skor terendah }}{6}
\end{gathered}
$$


Kemudian dilakukan teknik analisis data dalam penelitian ini adalah dengan menggunakan teknik analisis data kuantitatif dengan table frekuensi, dengan rumus :

$$
\mathrm{P}=\frac{F}{n} \mathrm{X} 100 \%
$$

\section{Keterangan :}

$\mathrm{P}=$ Presentase jawaban

$\mathrm{F}=$ Frekuensi jawaban

$\mathrm{n}=$ Jumlah keseluruhan responden

Dengan ketentuan :

$0 \%-25 \%$ : Tidak Baik

$26 \%-50 \%$ : Kurang Baik

$51 \%-75 \%$ : Baik

$76 \%-100 \%$ : Sangat Baik

(Arikunto, 2006)

Rekapitulasi Partisipasi Pemuda Tahap Perencanaan Program Organisasi Karang Taruna di Kecamatan Pagaran Kabupaten Tapanuli Utara

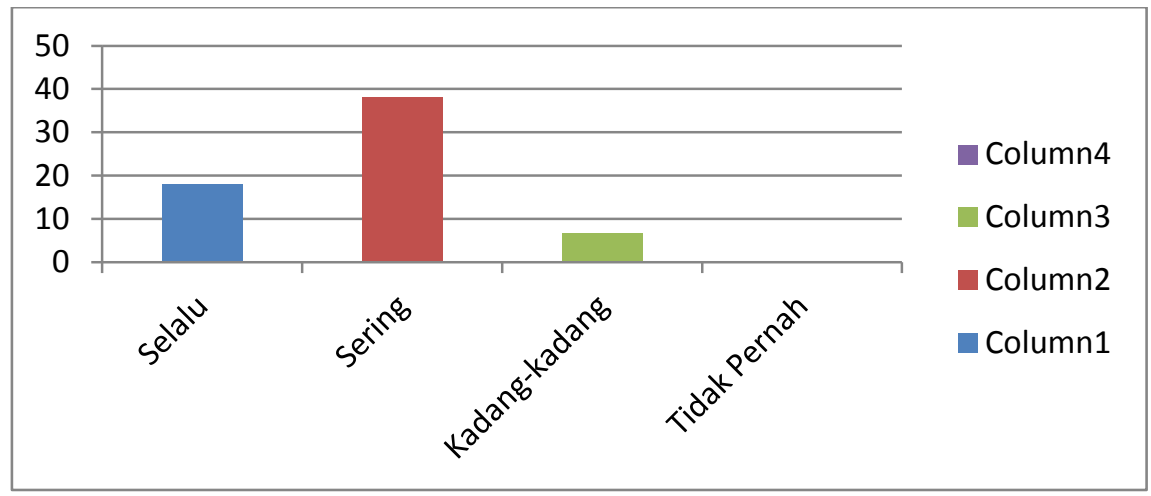

Gambar 1. Diagram Rekapitulasi Partisipasi Pemuda dalam Tahap Perencanaan Program Karang Taruna di Kecamatan Pagaran Kabupaten Tapanuli Utara

Dari gambar di atas terlihat bahwa penilaian dari tiap-tiap indikator terbagi menjadi 4 bagian yaitu : Selalu, Sering, Kadang-kadang dan Tidak Pernah. Grafik tahap perencanaan program memiliki skor rata-rata tertinggi adalah 38,1 yaitu pada penilaian "Sering", selanjutnya skor rata-rata kedua adalah 17,9 yaitu pada penilaian "Selalu", selanjutnya skor rata-rata 6,7 pada penilaian "Kadang-kadang" dan skor rata-rata terendah 0,3 pada penilaian "Tidak Pernah". Dari diagram di atas dapat disimpulkan 
bahwa pemuda Karang Taruna yang melakukan tahap perencanaan program kerja organisasi dimana rata-rata skor yang diperoleh sebesar 3,16 dapat dikategorikan "Baik".

Rekapitulasi Melakukan Tahap Pelaksanaan Program Karang Taruna di Kecamatan Pagaran Kabupaten Tapanuli Utara

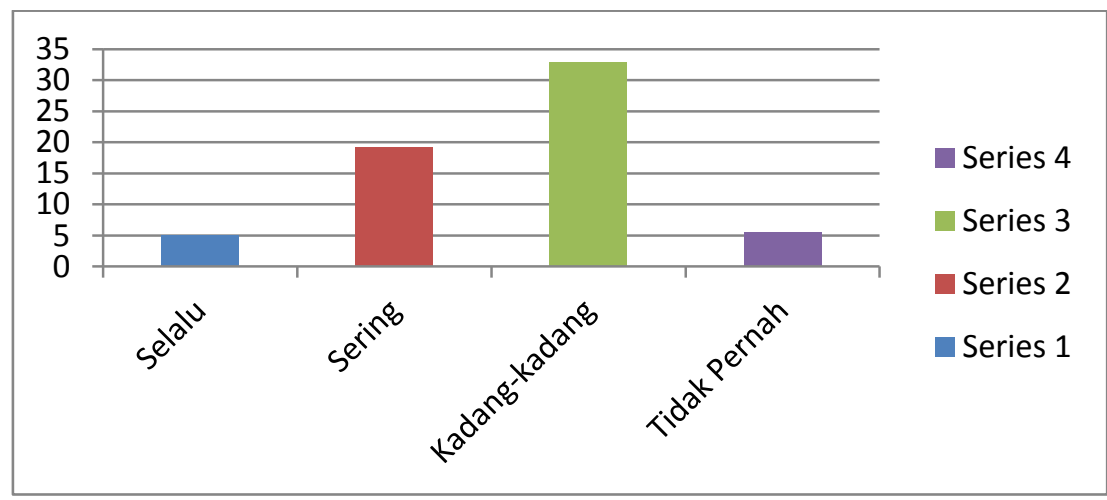

Gambar 2. Diagram Rekapitulasi Melakukan Tahap Pelaksanaan Program Organisasi Karang Taruna di Kecamatan Pagaran Kabupaten Tapanuli Utara

Dari gambar di atas terlihat bahwa penilaian dari tiap-tiap indikator terbagi menjadi 4 bagian yaitu : Selalu, Sering, Kadang-kadang dan Tidak Pernah. Grafik tahap pelaksanaan program memiliki skor rata-rata tertinggi adalah 32,9 yaitu pada penilaian "Kadang-kadang", selanjutnya skor rata-rata kedua adalah 19,3 yaitu pada penilaian "Sering", selanjutnya skor rata-rata 5,6 pada penilaian "Tidak Pernah" dan skor rata-rata terendah 5,1 pada penilaian "Selalu". Dari diagram di atas dapat disimpulkan bahwa pemuda Karang Taruna yang melakukan tahap pelaksanaan program kerja organisasi dimana rata-rata skor yang diperoleh sebesar 2,37 dapat dikategorikan "Cukup Baik".

Rekapitulasi Melakukan Tahap Pemanfaatan Hasil Program Organisasi Karang Taruna di Kecamatan Pagaran Kabupaten Tapanuli Utara

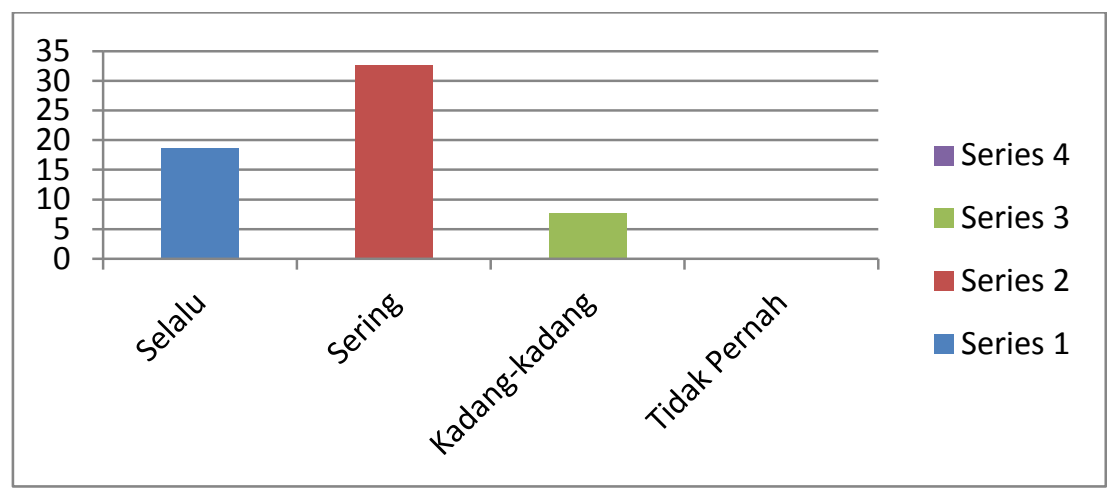

Gambar 3. Diagram Rekapitulasi Melakukan Tahap Pemanfaatan Hasil Organisasi Karang Taruna di Kecamatan Pagaran Kabupaten Tapanuli Utara 
Dari gambar di atas terlihat bahwa penilaian dari tiap-tiap indikator terbagi menjadi 4 bagian yaitu : Selalu, Sering, Kadang-kadang dan Tidak Pernah. Grafik tahap pemanfaatan hasil program memiliki skor rata-rata tertinggi adalah 32,6 yaitu pada penilaian "Sering”, selanjutnya skor rata-rata kedua adalah 18,7 yaitu pada penilaian "Selalu", selanjutnya skor rata-rata 7,7 pada penilaian "Kadang-kadang" dan skor ratarata terendah 0 pada penilaian "Tidak Pernah". Dari diagram di atas dapat disimpulkan bahwa pemuda Karang Taruna yang melakukan tahap pemanfaatan hasil program kerja organisasi dimana rata-rata skor yang diperoleh sebesar 3,14 dapat dikategorikan "baik".

Rekapitulasi Melakukan Tahap Pengevaluasian Program Organisasi Karang Taruna di Kecamatan Pagaran Kabupaten Tapanuli Utara

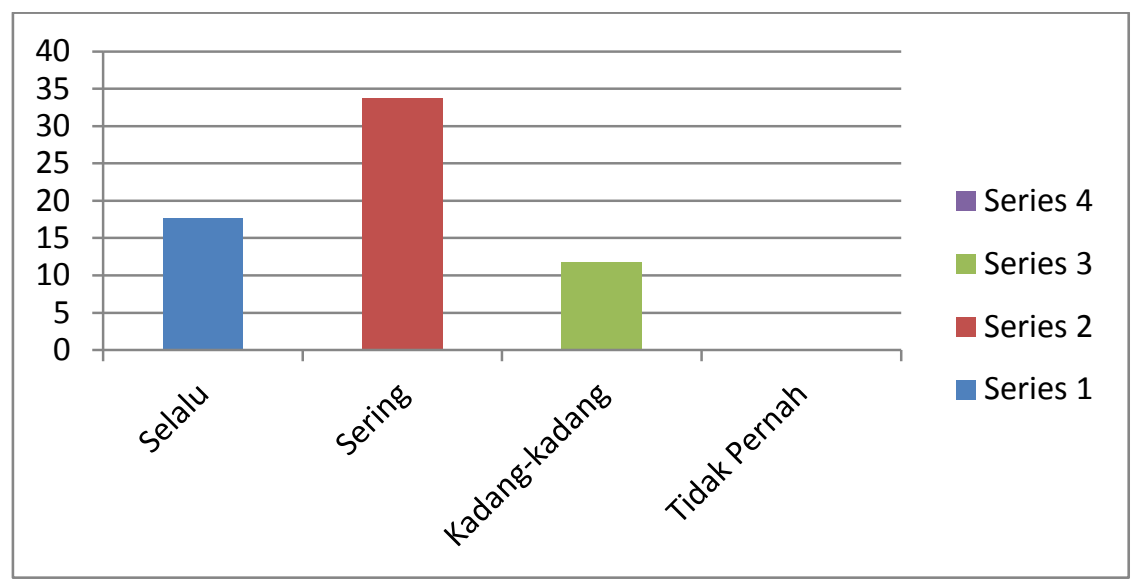

Gambar 4. Diagram Rekapitulasi Melakukan Pengevaluasian Program Organisasi Karang Taruna di Kecamatan Pagaran Kabupaten Tapanuli Utara

Dari gambar di atas terlihat bahwa penilaian dari tiap-tiap indikator terbagi menjadi 4 bagian yaitu : Selalu, Sering, Kadang-kadang dan Tidak Pernah. Grafik tahap perencanaan program memiliki skor rata-rata tertinggi adalah 33,7 yaitu pada penilaian "Sering", selanjutnya skor rata-rata kedua adalah 17,6 yaitu pada penilaian "Selalu", selanjutnya skor rata-rata 11,7 pada penilaian "Kadang-kadang" dan skor rata-rata terendah 0 pada penilaian "Tidak Pernah". Dari diagram di atas dapat disimpulkan bahwa pemuda Karang Taruna yang melakukan tahap pengevaluasian program kerja organisasi dimana skor rata-rata yang diperoleh sebesar 3,05 dapat dikategorikan "baik". 


\section{Rekapitulasi Partisipasi Pemuda dalam Memberhasilkan Organisasi Karang Taruna}

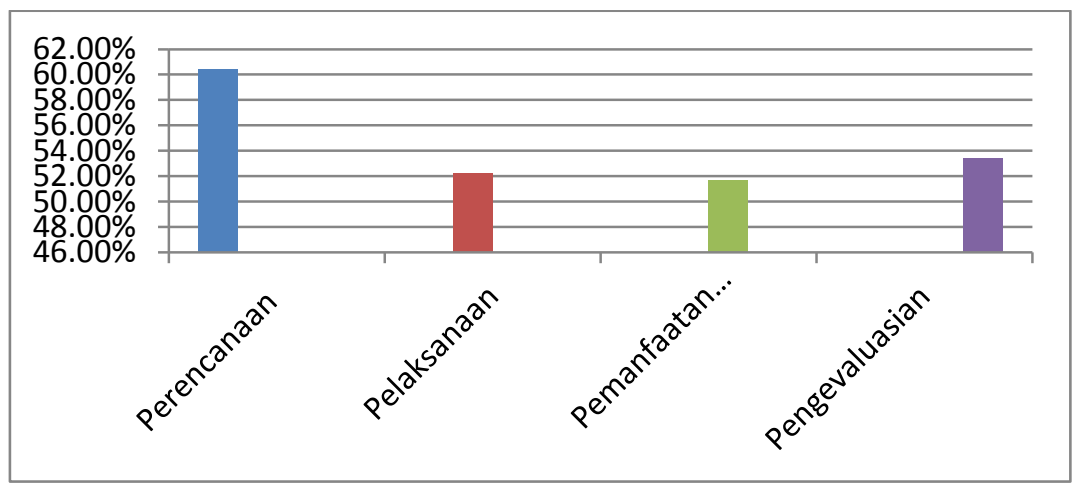

Gambar 5. Diagram Rekapitulasi Partisipasi Pemuda dalam Memberhasilkan Organisasi Karang Taruna

Dari Gambar di atas terlihat bahwa partisipasi pemuda dalam memberhasilkan organisasi Karang Taruna terbagi dalam 3 indikator. Grafik partisipasi tersebut memiliki skor rata-rata tertinggi adalah 60,4\% yaitu pada indikator perencanaan, selanjutnya skor rata-rata kedua adalah 52,2\% yaitu indikator pemanfaatan hasil, selanjutnya skor rata-rata ketiga adalah 51,7 \% yaitu pada indikator pengevaluasian program dan skor rata-rata terendah adalah 53,4 \%yaitu pada indikator pelaksanaan program. Dari diagram di atas dapat disimpulkan bahwa partisipasi pemuda dalam memberhasilkan organisasi Karang Taruna di Kecamatan Pagaran Kabupaten Tapanuli Utara dimana skor rata-rata yang diperoleh sebesar $60,4 \%$ sehingga partisipasi pemuda Karang Taruna tersebut dikategorikan baik.

\section{Uji kecenderungan Subvariabel Perencanaan Program}

Tabel 3. Hasil pengujian kecenderungan sub variabel peran pemuda dalam perencanaan program

\begin{tabular}{lccc}
\hline \multicolumn{1}{c}{ Kelompok } & Frekuensi & F. Relatif $(\%)$ & Kategori \\
\hline$\geq 34$ ke atas & 9 orang & $14 \%$ & Sangat Tinggi \\
$31-33$ & 18 orang & $29 \%$ & Tinggi \\
$28-30$ & 28 orang & $44 \%$ & Cukup Tinggi \\
$25-27$ ke bawah & 8 orang & $13 \%$ & Kurang Tinggi \\
Jumlah & 63 Orang & $100 \%$ & \\
\hline
\end{tabular}

Berdasarkan pada tabel di atas, dapat dijabarkan untuk subvariabel perencanaan program kategori sangat tinggi 9 orang sebesar 14\%, kategori tinggi 18 orang sebesar 29\%, kategori cukup tinggi 28 orang sebesar 44\%, dan kategori kurang tinggi 8 orang sebesar $13 \%$. Dengan demikian dapat disimpulkan bahwa partisipasi pemuda dalam perencanaan program cenderung cukup tinggi dibuktikan dengan $44 \%$. 


\section{Uji kecenderungan Subvariabel Pelaksanaan Program}

Tabel. 4. Hasil pengujian kecenderungan sub variabel peran pemuda dalam pelaksanaan program

\begin{tabular}{cccc}
\hline Kelompok & Frekuensi & F. Relatif $(\boldsymbol{\%})$ & Kategori \\
\hline$\geq 31$ ke atas & 27 & $43 \%$ & Sangat Tinggi \\
$26-30$ & 33 & $52 \%$ & Tinggi \\
$21-25$ & 3 & $5 \%$ & Cukup Tinggi \\
$16-20$ ke bawah & 0 & $0 \%$ & Kurang Tinggi \\
Jumlah & 63 & $100 \%$ & \\
\hline
\end{tabular}

Berdasarkan pada tabel di atas, dapat dijabarkan untuk subvariabel pelaksanaan program kategori sangat tinggi 27 orang sebesar 43\%, kategori tinggi 33 orang sebesar $52 \%$, kategori cukup tinggi 3 orang sebesar 5\%, dan kategori kurang tinggi 0 orang sebesar 0\%. Dengan demikian dapat disimpulkan bahwa partisipasi pemuda dalam pelaksanaan program cenderung tinggi dibuktikan dengan $52 \%$.

\section{Uji kecenderungan Subvariabel Pemanfaatan Hasil}

Tabel 5. Hasil pengujian kecenderungan sub variabel peran pemuda dalam pemanfaatanhasil

\begin{tabular}{lccc}
\hline Kelompok & Frekuensi & F. Relatif (\%) & Kategori \\
\hline$\geq 32$ ke atas & 34 & $54 \%$ & Sangat Tinggi \\
$29-31$ & 20 & $32 \%$ & Tinggi \\
$26-28$ & 9 & $14 \%$ & Cukup Tinggi \\
$23-25$ ke bawah & 0 & $0 \%$ & Kurang Tinggi \\
Jumlah & 63 & $100 \%$ & \\
\hline
\end{tabular}

Berdasarkan pada tabel di atas, dapat dijabarkan untuk subvariabel pemanfaatan hasil kategori sangat tinggi 34 orang sebesar 54\%, kategori tinggi 20 orang sebesar $32 \%$, kategori cukup tinggi 9 orang sebesar 14\%, dan kategori kurang tinggi 0 orang sebesar 0\%. Dengan demikian dapat disimpulkan bahwa partisipasi pemuda dalam pemanfaatan hasil cenderung sangat tinggi dibuktikan dengan $54 \%$.

\section{Uji kecenderungan Subvariabel Pengevaluasian Program}

Tabel 6. Hasil pengujian kecenderungan sub variabel peran pemuda dalam pengevaluasian program

\begin{tabular}{cccc}
\hline Kelompok & Frekuensi & F. Relatif $\mathbf{( \% )}$ & Kategori \\
\hline$\geq 34$ ke atas & 19 & $30 \%$ & Sangat Tinggi \\
$31-33$ & 12 & $19 \%$ & Tinggi \\
$28-30$ & 14 & $22 \%$ & Cukup Tinggi \\
25 - 27 ke bawah & 18 & $29 \%$ & Kurang Tinggi \\
Jumlah & 63 & $100 \%$ & \\
\hline
\end{tabular}


Berdasarkan pada tabel di atas, dapat dijabarkan untuk subvariabel pengevaluasian program kategori sangat tinggi 19 orang sebesar 30\%, kategori tinggi 12 orang sebesar 19\%, kategori cukup tinggi 14 orang sebesar 22\%, dan kategori kurang tinggi 18 orang sebesar 29\%. Dengan demikian dapat disimpulkan bahwa partisipasi pemuda dalam pengevaluasian program cenderung sangat tinggi dibuktikan dengan $30 \%$.

\section{DISKUSI}

Hasil penelitian ini mengungkapkan bahwa semakin aktif partisipasi pemuda maka semakin baik organisasi Karang Taruna berlangsung. Dari hasil penelitian ditemukan bahwa tingkat kecenderungan masing-masing subvariabel sebagai berikut:

Dilihat dari hasil uji kecenderungan subvariabel partisipasi pemuda Karang Taruna Kecamatan Pagarandalamperencanaan program pada kategori sangat tinggi $\geq$ 34 sebesar 14\%, kategori tinggi dengan rentang skor 31 - 33 sebesar 29\%, kategori cukup tinggi dengan rentang skor 28 - 30 sebesar $44 \%$ dan kategori kurang tinggi dengan skor $\leq 27$ sebesar $8 \%$. Hal tersebut menunjukkan bahwa peran pemuda cenderung tinggi dan cukup tinggi.Oleh karena itu, diperlukan upaya untuk lebih meningkatkan partisipasi pemuda dalam perencanaan program agar organisasi dapat berjalan sebagaimana mestinya.

Hasil uji kecenderungan subvariabel partisipasi pelaksanaan program organisasi Karang Taruna Kecamatan Pagaran dengan kategori sangat tinggi $\geq 31$ sebesar 43\%, kategori tinggi dengan rentang skor 26 - 30 sebesar 52\%, kategori cukup tinggi dengan rentang skor $21-25$ sebesar 5\% dan kategori kurang tinggi dengan skor $\leq 20$ sebesar $0 \%$. Untuk tahap pelaksanaan program termasuk kategori cukup tinggi dengan 52\%. Dari hasil penelitian menunjukkan bahwa partisipasi pemuda Karang Taruna dalam pemanfaatan hasil pada umumnya sangat tinggi dengan skor $\geq 32$ sebesar $54 \%$, kategori tinggi dengan rentang skor $29-31$ sebesar 32\%, kategori cukup tinggi dengan rentang skor 26 - 28 sebesar $14 \%$ dan kategori kurang tinggi dengan skor $\leq 25$ sebesar $0 \%$. Untuk tahap pelaksanaan program termasuk kategori tinggi dengan 52\% yang berpendapat bahwa organisasi sangat baik bagi pemuda untuk menyalurkan bakat dari tiap-tiap anggota dan memberikan arah kepada anggota untuk melakukan kegiatan yang positif dan meningkatkan kerjasama antar anggota. Dari hasil penelitian menunjukkan bahwa partisipasi pemuda Karang Taruna dalam pengevaluasian pada umumnya sangat tinggi dan kurang tinggi. Sangat tinggi dengan skor $\geq 34$ sebesar 30\%, kategori tinggi 
dengan rentang skor 31 - 33 sebesar 19\%, kategori cukup tinggi dengan rentang skor 28 - 30 sebesar 14\% dan kategori kurang tinggi dengan skor $\leq 27$ sebesar 29\%. Untuk tahap pengevaluasian program terbagi menjadi kategori sangat tinggi dan kurang tinggi. Sebagian anggota memberi penilaian terhadap berlangsungnya program kegiatan Karang Taruna dan sebagian anggota tidak memberi penilaian terhadap program yang dijalankan organisasi Karang Taruna.

\section{PENUTUP}

Partisipasi pemuda dalam memberhasilkan organisasi Karang Taruna di Kecamatan Pagaran Kabupaten Tapanuli Utara dimana skor rata-rata yang diperoleh sebesar 60,4\% pada indikator perencanaan program organisasi yang tergolong pada kategori "Baik", pada indikator pelaksanaan program mencapai nilai rata-rata 52,2 \% yang tergolong pada kategori "Baik", pada indikator pemanfaatan hasil mencapai nilai rata-rata 51,7 \% yang tergolong pada kategori "Baik", pada indikator pengevaluasian program mencapai nilai rata-rata 53,4 \% yang tergolong pada kategori "Baik". Hal ini dapat disimpulkan bahwa benar partisipasi pemuda dapat memberhasilkan organisasi Karang Taruna di Kecamatan Pagaran Kabupaten Tapanuli Utara.

Partisipasi pemuda Karang Taruna Kecamatan Pagaran dalam perencanaan program pada kategori sangat tinggi $\geq 34$ sebesar $14 \%$, kategori tinggi dengan rentang skor 31 - 33 sebesar 29\%, kategori cukup tinggi dengan rentang skor 28 - 30 sebesar $44 \%$ dan kategori kurang tinggi dengan skor $\leq 27$ sebesar $8 \%$. Hal ini menunjukkan bahwa pemuda lebih aktif dalam partisipasi perencanaan program organisasi Karang Taruna.

Dengan demikian, Badan Pengurus Harian organisasi Karang Taruna Kecamatan Pagaran Kabupaten Tapanuli Utara perlu melakukan peningkatan pelaksanaan program kerja yang dilakukan anggota mengingat hasil dari partisipasi dalam tahap pelaksanaan "cukup baik" agar program kerja yang telah dibentuk berjalan dengan baik. Pemuda Karang Taruna Kecamatan Pagaran Kabupaten Tapanuli Utara harus meningkatkan kegiatan gotong royong selain meningkatkan kebersihan lingkungan juga agar dapat menjalin kerja sama yang baik antar anggota dan masyarakat setempat. Pemerintah setempat harus lebih mendukung serta memberikan bantuan agar program organisasi Karang Taruna di Kecamatan Pagaran Kabupaten Tapanuli Utara berjalan sebagaimana mestinya dan demi mendukung karakter pemuda yang lebih baik untuk kedepan. 


\section{DAFTAR PUSTAKA}

Arikunto, S. 2006. Metodologi Penelitian. Jakarta: Rineka Cipta 2006. Prosedur Penelitian Suatu Pendekatan Praktis (Edisi Revisi VI). Jakarta: Rineka Cipta

Dinas Kesejahteraan Dan Sosial PROVSU Penumbuhan dan Pengembangan Karang Taruna APBD. 2010. Pedoman Dasar Karang Taruna

Mardikanto. 2015. Pemberdayaan Masyarakat. Bandung: Alfabeta

Pedoman Karang Taruna Desa Sipultak Kab. Tapanuli Utara

Peraturan Pemerintah No 0059 Tahun 2013. Pengembangan Kepemiminan Pemuda

Permensos RI. 2014. Pedoman Dasar Karang Taruna

Rizqina, Finna. 2010. Partisipasi Masyarakat. Yogyakarta: Andi Offset

Sawitri. Nurul. 2014. Partisipasi Pemuda dalam Program Karang Taruna Desa Kupang Kecamatan Ambarawa. Semarang. Universitas Negeri Semarang

Slamet. M. 2010. Proses Belajar Mengajar. Jakarta: Bumi Aksara

Sudijono, A. 2009. Pengantar Statistik Pendidikan. Jakarta: Rajawali Pers

Sugiyono. 2013. Metode Penelitian Pendidikan. Bandung: Alfabeta ,2014. Metode Penelitian Kuantitatif dan Penelitian Kualitatif dan R\&D. Cetakan Ke-20. Bandung : Alfabeta.

Suryana, S. 2010. Pemberdayaan Masyarakat. Bandung: Alfabeta

Suryosubroto. 2012. Hubungan Sekolah Dengan Masyarakat. Jakarta: Rineka Cipta Tim Dosen. 2013. Pedoman Penulisan Skripsi. FIP. Unimed Undang-Undang Dasar Negara Republik Indonesia No 40 Tahun 2009. Kepemudaan. 